\title{
SPAIS $=$
}

\section{Historical Re-enacting and Affective Authority: Performing the American Civil War ${ }^{1}$}

\author{
Brad West \\ University of Bristol \\ (C) Brad West
}

School of Sociology, Politics and International Studies

University of Bristol

Working Paper No. 06-12

Brad West is a lecturer in sociology at the University of Bristol. He undertakes empirically informed theoretical research focusing on the significance of leisure for contemporary national identity and collective memory. This has included ethnographic work on battlefield tourism at the WWI Gallipoli battlefields and Vietnam's Cu Chi Tunnels and public sphere analysis of the 2004 South Asian Tsunami and the 2002 Bali bombings. His article analysing the latter won the 20082010 Best Paper Award in the Journal of Sociology. He can be contacted at brad.west@bristol.ac.uk 
Historical Re-enacting and Affective Authority: Performing the American Civil War

Brad West

University of Bristol

\begin{abstract}
In applying performance analysis to the nation, cultural sociology has provided nationalism scholars with a powerful alternative to ritual studies in accounting for symbolic power. However, I argue that this perspective is limited by conceiving of performance as the sum of its production and reception by audiences. This paper examines American Civil War re-enacting to highlight the need for also considering the experience of participants themselves in national performances. Through ethnography and interviews with Civil War re-enactors local to Gettysburg I outline how attaining a sense of 'living history' provides an affective authority for re-enactors in interpreting the past. This motivates re-enactors to undertake voluntary educational activities, including at schools and museums, where orthodox understandings of the past are promoted. This particularly occurs through challenging the dominant belief that the war was fought over the issue of slavery.
\end{abstract}




\section{Introduction}

The analytic frame of performance has become increasingly popular amongst cultural sociologists in analysing the nation. Where nationalism scholars have traditionally conceptualised symbolic action in reference to ritual, this has been dogged by an empirical focus on state sanctioned remembrances and dialectical debates about the primordial or instrumental nature of national integration. Where nations and nationalism theory in recent years has provided an alternative to this in the study of an everyday nationhood (Billig 1995; Edensor 2002; Fox and Idriss-Miller 2008), the concern of this literature is with fairly routine and ordinary activities, de-emphasising the transformative role of heightened emotional energy. Performance studies of the nation by cultural sociologists, in contrast, have applied the dramaturgical notions of acting, genres, stages, scripts and audiences in ways that see the symbolic as central to contemporary social and political change. This is illustrated in a broad array of empirically informed studies where performative social action is seen to be orientated by engagement with national identities and patriotic myths. This includes analysis of the aesthetical aspects of state power (Berezin 1997; Mast 2006), oppositional social movements (Conway 2007; Taylor 2003), terrorist acts (Alexander 2004a; West 2008a) and post-Fordist consumption logics (Sturken 2007; West 2008b). Where social theory has tended to either comprehend the nation as being determined by its modernist origins or disintegrating in the face of global social and economic expansion, this performance literature avoids such structural determinism, envisioning multiple futures with the meaning and role of the nation tied to the outcome of 'rituallike' engagements with it. This is not to argue that performances are always significant in shaping the nation but rather they have a potential to be consequential, with the emphasis being on their variable influence and contingent outcomes. In Alexander's terms where in simpler societies ritual would automatically result in social solidarity by creating a "fusion" between performance and audience, to be effective in complex societies performances must be interpreted as compelling, undertaking a project of "re-fusion" (Alexander 2004b: 529).

Despite the analytic advantages of this perspective in analysing the nation, I argue that it overly associates the symbolic power of performance with its production and reception by audiences. This conceptualisation is best illustrated by Alexander's theory of cultural pragmatics in which he expands upon interactionist dramaturgical theory to provide a macro account of social performances, concentrating on the extent to which they "stand or fall on their ability... to create, via skilful and affecting performance, the emotional connection of audience with actor and text" (Alexander 2004b: 547). ${ }^{2}$ Undoubtedly the principal political significance of many performances derives from their interpretation by spectators and their subsequent influence within the contemporary public sphere (Jacobs 2000). However, symbolic power also needs to be considered in terms of the affect of performance on the performers themselves. This is particularly the case for participatory forms of national performance where a significant number of actors attain a distinctive embodiment of the sacred symbol to which the performance is orientated (Conway 2007). A concern with the experience of performance has been a traditional strong suit in the contemporary micro tradition of performance analysis (Denzin 2003), particularly in relation to the identity politics of gender (Butler 1999) and other less formal forms of political participation (Melucci 1996). However, it would be problematic to simply apply such literatures to national performances as from the perspective of cultural sociology they fail to empirically 
connect how cultural experiences and representations work in driving social action and change.

To document "what really happens" (Alexander 2003:14) in national performances I propose that Geertz's $(1973 ; 1983)$ concern with the role of sacred symbols in orientating behaviour should be utilised in combination with the cultural pragmatics approach. Where cultural pragmatics provide a frame to account for the difficulties of meaning-making in performances, Geertz $(1973 ; 1983)$ allows for an analysis of the way this production of culture intersects with the attainment of certain "moods and motivations" (1973:90) amongst performers. The emphasis here is not only with the emotive dimension of engaging with the symbolic realm but the way this provides actors with a "model for" subsequent social and political action. Where this Geertzian cultural systems perspective has been previously applied to national collective memory (Schwartz 1996; West 2008a), these studies have focussed on emotional energy and shifting historical interpretation in terms of social integration. In contrast, this paper uses Geertz to understand the recreational pursuit of American Civil War (from here referred to as the Civil War) re-enacting, a case involving a heightened symbolic engagement with the nation by a small section of the community, one that fosters societal conflict rather than social consensus.

Civil War re-enacting is a participatory form of national performance with an estimated 50,000 participants in the United States. ${ }^{3}$ It is undertaken independent of the state and in tension with state institutions such as the National Parks Service, which have designated it as an inappropriate way of remembering warfare (Stanton 1999:23). Its principal participants are politically conservative white working class men. As we will see, while these re-enactors conceive of themselves as a minority, it would be problematic to apply the standard ethnographic approach to performance that stresses its emancipatory potential for the oppressed. A straight adoption of the cultural pragmatics perspective that comprehends the cultural and political significance of performance in relation to the meaning it offers an audience is also problematic. While re-enactments do often attract spectators, seldom do they exceed the number of participants and there are also several re-enacting activities at which a viewing audience is prohibited (cf. Thomson 2004). Perhaps for this reason existing studies of re-enacting have been dominated by a postmodern perspective which has interpretively conceived of it in relation to the supposed inherent qualities of this commemorative form. ${ }^{4}$ By contrasting re-enacting with established modern forms of remembrance this postmodern literature has argued that their playful nature indicates a weakening of societal ties to the nation and national history.

Drawing on a performance perspective this paper provides an alternative understanding of re-enacting by drawing on historical document analysis undertaken at the United States National Archives at College Park and ethnographic research of re-enactments and living history displays in Gettysburg, Pennsylvania, including interviews with 22 white male re-enactors, 10 Confederate and 12 Union. The vast majority of re-enactors in the interview sample would be classified as being mainstream, in that they go to considerable effort to portray the past authentically, including having period like stitching on their uniforms and cooking and eating food similarly to soldiers in the war. While they typically avoid any modern comforts for camping, many do use period cots for sleeping, something that would only have been the privilege of officers in the war. In socialising and interacting with other over a re- 
enactment weekend these re-enactors tend to somewhat flexibly move in and out of historical character in terms of their conversation tone and subject matter. Two informants in the sample might be classified as "hardcore" re-enactors, those that seek complete immersion into their role, typically staying character for entire reenactments and sleeping rough in camps which are often set up away from those of mainstream re-enactors or avoiding large re-enactments and those that allow spectators. In several ways the data support postmodern insights, in particular in relation to its historical emergence and the problems of the gene in portraying a meaningful past. However, by also examining re-enacting in terms of the emotional experience that the performance affords, a new comprehension of its political significance emerges. Central to this is re-enactors attaining an affective authority, the term I use to refer to claims of accurately knowing the past on the basis of an emotional and embodied experience of it. This is subsequently utilised by majority of re-enactors who engage in volunteer educational activities in schools and with the public at museums and re-enactments. Through these they promote an orthodox understanding of the past, challenging dominant understandings of the war and the institutional figures which uphold them. While the ideologies being propagated may reflects the pre-existing worldviews of most re-enactors, it is argued that it is the experience of 'living history' within the act of re-enacting and their status as a reenactor which allows them to engage with the public sphere in this way.

\section{The history of re-enacting}

As outlined above, in the absence of a significance audience, academic studies of Civil War re-enactments have been dominated by an interpretive perspective. Most influential has been the postmodern paradigm which sees the search for authentic representation amongst re-enactors and their aim to 'time-travel' as reflecting the loss of deep forms of engaging in history (Hall 1997; Kaufman 2007; Radtchenko 2006). Drawing on Baudrillard (1983) the emphasis is placed on re-enacting representing a hyper-reality in which the past becomes an impotent symbol for embodying sacred meaning and orientating collective identity. While the limitations to such understandings will be explored below, one of the strengths of this postmodern literature is in linking re-enacting to a general shift in the way individuals and groups engage with the national past. In particular re-enacting is connected to the broad emergence of living history leisure forms. These involve the use of real or recreated historical artefacts, costumes and dramatic displays to represent the past and significantly achieve knowledge of it (Anderson 1982; 1985). This way of representing and understanding the past does not as much directly challenge established historical narratives as provide an alternative paradigm for comprehending the past (Agnew 2007; During 2007). Rather than engaging in the formal and rational approaches that professional historians use to attain knowledge, focusing on understanding broad historical shifts and issues of geo-political power, living history has a concern with interpreting the past in terms of petite narratives. Principally this involves coming to an understanding of history through attempting to know it from the perspective of the ordinary person's experience of it. As such living history provides a paradigm for amateur historians and various history enthusiasts to know and engage with the past. However, it is also an increasingly prevalent mode of historical display in many museums, and the basis of whole historical tourist precincts, such as Colonial Williamsburg in the United States or le puy du Fou in France, where costumed interpreters act, work and dress as they might have done in the era. Such a "simulation of life in another time" (Anderson 1985:3) is also evident 
in highly rating historical reality televisions series such as The Trench (UK), Frontier House (US), Pioneer Quest (Canada) and The Colony (Australia).

It has been widely argued by nationalism scholars that these assumptions about the loss of meaningful engagement with history fail to appreciate the enduring cultural influence of the nation (Calhoun 2003; Shils 1995; Smith 1995). However, as outlined below, in employing an empirical performance analysis that only focuses on its production one would also left to conclude that this is a "de-fused" rite (Alexander 2004b). Certainly the origins and subsequent rise of Civil War re-enacting is illustrative of a well document societal shift away from ritual towards culturally weaker performance forms (Alexander 2004b; Schecher 1976; Turner 1982). The origins of Civil War re-enacting itself are to be found in attempts by the state to create a consensus on history at a time of increasing cultural diversity. The Centennial commemorations of the Civil War (1957-1965), in particular, saw re-enactment emerge as a key commemorative form. Where it may be true that the victors write history, in this Civil War remembrance organisers too were highly sensitive to the potential for commemorations to create controversy and conflict. For organisers reenactment was seen as a de-politicised way of remembering a 'difficult past' without creating political divisions (Bodnar 1991:213; Spillman 1997:208). ${ }^{5}$ For a similar reason the federal organisers also undertook a decentralisation strategy that allowed for state and locally organised celebrations, with re-enactments particularly prominent amongst these in the Southern states. While many of these re-enactments encouraged public participation, with many seemingly willing to pay out of their own pockets to be involved, other re-enactments were spectator focussed. This included the largest reenactment of the centennial, the 1961 recreation of the Battle of Manassas, undertaken by members of the U.S. Army on the site of the original battle with the permission of National Park Service. The involvement of the armed forces was frequently legitimised by framing the Civil War as the origins of modern warfare (Public Information Office 1962).

The difficulty for the state was not that either form of re-enactment failed to fuse with the majority of audiences. Rather that their popularity was not as de-politicising as assumed, ${ }^{6}$ evoking fears amongst elites about a resurgence of sympathy for the confederate cause. The concern that re-enacting had revived confederate parochialism is illustrated in the objections to it by Ralph McGill, the well known antisegregationist editor and publisher of the Atlanta Constitution. He declared that reenactments were responsible for the rise of a neo-confederacy with people "wearing sleazy-imitations of Confederate uniforms, growing beards, making ancient wounds bleed again... and otherwise doing a great disservice to the memory of those who fought and died" (quoted in Bodnar 1991: 214). The Centennial Commission, whose most influential members were citizens with military backgrounds, were sensitive to such criticism and from December 1961 the Centennial Commission went on record "opposing any and all battle re-enactments" (Robertson 1962). It declared that "reenactments possess too much celebratory spirit and too little commemorative reverence... This soldier playing mocks the dead (quoted in Bodnar 1991:215). Where the decentralisation strategy of the Centennial organisers saw the public continue to flock to re-enactments that were arranged by local organising committees, these would largely mark the end of the state's utilisation of re-enacting as a commemorative form in remembering warfare. 
Civil War re-enacting would re-emerge years later, however, in the guise of a mainstream leisure rite. From a performance perspective this must be understood as the outcome of various performative variables, such as the establishment of audiences and the supply of props rather than simply as filling the commemorative vacuum left by state disengagement. The popularity of recreational re-enacting developed incrementally with a number of relatively small participatory re-enactments and larger spectator orientated ones. These helped to raise interest in the pursuit and facilitated participation within it. The $125^{\text {th }}$ anniversary of the Civil War was particularly significant. The Battle of Manassas re-enactment in 1986, involving six thousand reenactors, is often cited by contemporary re-enactors as a turning point in attracting recruits (Hadden 1996 :5). Stock footage of this re-enactment was subsequently used in various Civil War documentaries, something which subsequently saw recreational Civil War re-enactors being used as acting extras in Civil War feature films such as sae and the Hollywood film Gettysburg (1993) (Hadden 1996:6). The professional choreographed spectator focussed re-enactments, however, are equally significant in the development of recreational re-enacting as their scale created a supply of replica uniforms and armaments which helped equip subsequent recruits to Civil War reenacting. For example, the Battle of Antietam saw the ordering of a total of 260,000 musket charges "produced in the same manner as they were a century ago, including the type of paper wrapping to the recommended knot in the string that holds the charges together", nine thousand separate items of wardrobe requiring 83 shipping trunks (Spillman:x). The rise of the North-South Skirmish Association (NSSA) who engaged in shooting competitions with original and reproduction Civil War pistols, rifles and cannons was similarly important in supplying replica armaments. NSSA also provided the required knowledge of how these weapons could be safely used with black powder. This not only provided a greater authenticity for recreational reenacting but fostered the activity in providing the material culture necessary to achieve the type of authenticity demanded by living history (Agnew 2007). From an ethnographic study of Civil War re-enacting, for example, Strauss (2003) argues that the uniform is particularly significant, being "used to step into character and to drape history over the shoulders of re-enactors... [W]ithout... the stage upon which history was replayed evaporates..." (2003: 159). The sacredness of the uniform is also indicated in a Civil War re-enacting handbook's statement that "when you wear these clothes, they will have much more significance than anything else you have ever worn (Hadden 1996: 35).

\section{The production of re-enacting}

A key characteristic of the performance perspective is that social action cannot be reduced to the consideration of social structure, that even where scripts are consistent, each performance is unique and distinctive, being the outcome of different embodied interplays between stages, actors, props, and audiences. As a performance genre though Civil War re-enacting suffers from several inherent difficulties in providing realistic and authentic representations that "fuse" with audiences, the basis of which Alexander largely judges the political significance of performances (Alexander 2004b:529). As a voluntarily organised recreational pursuit its portrayal is altered by a number of production pragmatics. The selection of a stage is of key importance. Where the site where blood was spilt has an inherent sacredness, as noted above the United States National Parks Service has banned any form of re-enactment being undertaken on the original battlefields. ${ }^{7}$ The most attractive surrogate for reenactments are open fields close to original battlefields. The $135^{\text {th }}$ Gettysburg 
anniversary re-enactment 1998, still the largest re-enactment with an estimated 40,000 participants, took place at Bushy Farm, six miles from the battlefields. However, typically greater improvisation is required for re-enactments, particularly for those that occur elsewhere in the United States, or indeed internationally, where the Civil War was not fought. ${ }^{8}$ For example, in opening scenes of Jessica Yu's documentary Men of Reenaction (1994) West Coast re-enactors stage a re-enactment on a Californian beach.

Various other difficulties are encountered in the choreographing of scripted battles. While a significant degree of effort is taken in arranging the performance, portrayals remain highly contingent as re-enactments are reliant upon cooperation between and within the multiple independent units of the two armies of re-enactors. A key issue is the willingness of participants to conform to certain role restrictions. The issue of limiting key protagonists is typically not problematic. In the Pickett's Charge reenactment at Gettysburg, for example, there can only be one person playing General Robert Lee. Similarly within any unit there can only be one commanding officer and so forth. These issues are avoided by the influence of central organising bodies. However, there is also less demand to play such elite roles than might be assumed. Reflecting the ethics of living history, a majority of re-enactors are happy to be portraying soldiers of lower rank believing that in this role they can best honour the majority of those who lost their lives in the Civil War. In Turner's terms this status reversal, that sees an inversion of hierarchies which normally hold sway in society, is a key characteristic of liminal rites (1969).

"I think what we do is basically a man in the ranks and the reasons we do is to teach and to sort of honour what they did. These are men who gave everything... I like the ones I am doing, it is a nameless man in the ranks" (Union Private, Retired Prison Guard, Age 42)

"Private (chose to re-enact) cause they were the ones out there fighting... the low lifes of the Confederate army and they were the dogs and they did the work and a lot of them died and they were all Americans" (Confederate Private, Truck Driver, Age 28)

A successful re-enactment also requires the involvement of re-enactors of both armies. While public concern with Civil War re-enacting has been with portrayals of the confederacy, evoking fears that it encourages nostalgia for a pre-Civil Rights beliefs (Horwitz 1998; Farmer 2005), re-enacting is as popular in the northern states of America and amongst those who want to portray the Union. Contrary to the popular belief of many outside of the subculture, the residency or heritage of re-enactors does not determine the selection of units and armies. There are of course some re-enactors that have either a parochial attachment or family lineage which they feel directed their decision to portray either the Union or Confederate army. However, a vast majority in the interview sample for this study expressed more pragmatic and circumstantial factors in coming to join a particular unit. Significantly, when re-enactors clearly associated themselves with a particular army, this was linked to their perceived personality traits or romantic notions of the North and the South rather than any lingering geographic divisions in the United States. As will be explored later in the paper, the cultural attachment for re-enactors is most prominently to the living history genre itself and its approach to understandings past than to a particular side of the 
Civil War. This is illustrated in a popular car bumper sticker within the recreational pursuit: "REENACTORS: A BAND OF BROTHERS BONDED IN HISTORY".

"Originally I am from Connecticut and Pennsylvania...I came to a Gettysburg re-enactment to get contacts. And initially I was walking around the Union camps and many of them had told me that to come back when you get all your gear...so I start wandering the Confederate camps ... and in five minutes I had a uniform, accoutrements, a rifle in hand and cartridges and I was ready to take the field that day. And I fully didn't expect to do that." (Confederate, Age 38, Museum Director)

"I had always wanted to do a Union impression (as) primarily the four ancestors that I know of that fought in the American Civil War all fought for the Union. However ... the church I was going to at the time in Frederick Maryland, a man that went to that church was in the $9^{\text {th }}$ Virginia Cavalry... the guys were really into it and you know really into historical accuracy doing a real quality impression... And so I went ahead and joined that unit and really enjoyed it." (Union private (previously Confederate) Age 40, Military Soldier)

"I considered Confederate because it just suits my personality better. I am a Pennsylvania resident. I've grown up in Pennsylvania. I've always been in a state of the Union and you know personally I can understand why they did it but I've always been the type of person takes (the side) for the underdog and during the war the Confederates... (Confederate, Age 21, Labourer)

The ability of re-enactments to resemble original battles in terms of troops, of course, is not reliant upon the national totals of re-enactors but a fairly equal distribution of re-enactors from both armies at any particular battle. Unequal numbers is a significant problem and one addressed by what is known as galvanizing, where re-enactors willingly switch sides to improve the historical accuracy of the re-enactment. Such is the frequency of this practice that various re-enactors have both a union and confederate uniform. Units themselves also have spare uniforms and equipment to facilitate galvanising. Where various re-enactors do not participate in galvanizing this is often for reasons relating to their desire to achieve authenticity in their portrayal of a soldier rather than for ideological reasons. Those who have galvanized though note how the alternative script of performing a different army provides for a different emotional experience.

"I strive to do a $100 \%$ impression of what I do which requires a great deal of time, investigation, investment in equipment and research... to turn around and do a $15 \%$ impression of a federal would be counter productive to what I am trying to achieve.(Confederate, Age 38, Museum Director, I16, t5)

"I kind of felt strange shooting against my own unit. But ah, it was a unique experience. I mean I am in it to learn and have a good time and I just got another new point, a northern view point that's all. It just shows a little bit more respect to the people I am fighting against, seeing their side" (Confederate, 40 years old, Technician) 
Even in the movie Gettysburg I played a Confederate for a couple of days of filming. And you do it differently. It just feels different. You're a Rebel.

You're rebelling. It feels strange shooting at your flag too. It's hard to explain. You definitely feel different... In a way you feel more free in a way..." (Union sergeant, Age 46, Library worker)

Once such organisational issues are addressed, particular roles in the battle must be assigned to units and individuals within them. An ongoing issue in this regard is the willingness of re-enactors to die in battle scenes. During the Civil War cannon fire and musket volleys killed many before battle lines met and hand to hand conflict ensued. However, amongst re-enactors there is the propensity to want to engage in the final stages of fighting, to come face to face with the enemy. To combat this problem in accurately portraying the past some units draw numbers randomly from a hat deciding who and when members will become fatalities. In other units the commanding officer determines when particular individuals will fall, and who will be dead and who will be injured. Volunteers also come forward to fall early from the older and less aerobically fit members of the group. Despite such strategies in choreographing battles, circumstance often results in historical inaccuracy and indeed in the battles going completely off script or failing. As outlined in the quotes below, in local re-enactments this is most likely to occur as a consequence of low levels of participation; whereas in larger re-enactments it is more likely to emerge as reenactors become swept up in the emotional energy of the performance.

"Here in Gettysburg... it was $1982 \ldots$ There was 286 Confederates at the event and there was only twenty Federals, that was it. Not one of the Confederates would galvanize to do federals ...One canon went off, all the other five are loaded, one canon went off, everyone went down ... The battle lasted one minute... And when we did the next one some of the Confederates galvanized ...” (Union, Age 41, Handicap Instructor)

"Like when we did the Sunken Road at Antietam... we finally went up for a final push, we were to cross the fence, cross the road to 50 yards beyond and then the battle was going to be over. Well we got up there ... hand to hand combat in most reenactments is a no no... And that's all it was! We got across the fence and the Confederates didn't want to (relinquish) their spot so we got across and it was like real. And I watched guys swinging rifles and stuff... They couldn't have stopped it if they wanted to... after it was over everybody was hugging everybody else and crying and its just a feeling, it's just unreal. (Union Captain, Age 40, Motor Mechanic)

As explored below, where these emotionally charged moments misrepresent the past and as such have the potential to diminish the experience of historical accuracy for the viewing audience and other participants, such moments for re-enactors can also often provide times in which they conceive that they have attained a true comprehension of what it was like to be involved in the Civil War. This is illustrative of the competing aims of re-enactment: to mimetically portray the past and to achieve mnemonic engagement with it.

\section{Achieving living history}


The highly contingent nature of recreational re-enacting is something that differentiates it from both traditional solemn forms of commemorating warfare in the West (Winter 1995) and the symbolic action of participating in 'disciplined' military training and tactical exercises (Foucault 1977; King 2012). In many ways this reflects the experience of re-enacting as a recreational pursuit. For participants re-enactments provides time to be social with friends and family, escaping from the complexities of the modern world.

"... you're you go there just to be with the friends. That's the whole point. You're actually going, not to have fun, you're going there to be with friends. And that's the one thing that gets you all together." (Union, Age 41, Handicap Instructor)

"I have a wife and three children and they come out and have a great time. The kids run around with other kids. My wife talks to the other women and its all just like a family atmosphere. We're all just one big happy family" (Confederate, Age 21, Labourer)

To understand re-enacting in terms of its carnivalesque character (Bakhtin 1984), however, is to neglect the sacredness that re-enactors also attach to it (Geertz 1972). Following the logics of living history the aim of re-enacting is learning of the past and in so doing honouring it. To do so re-enactors willingly endure various discomforts, including the wearing of stifling wool uniforms, sleeping on the ground and not bathing for entire weekend and sometimes for an entire week. While re-enacting is only a simulation of fighting it does also involve a level of danger, in particular that associated with explosives, cavalry and the acting out of hand to hand combat scenes.

Brogans are murder on your feet. Your feet hurt. In the summertime the heat is unbearable....Bad enough ... in shorts and t-shits, but you start talking about wool uniforms... (Confederate Captain, Age 50).

I've seen people die. I've seen people get ram rods put through them. I've lost my sight. I've been knocked out, got stiches, heat exhaustion... I've seen people get trampled and men fall off horses... (Confederate, Technician, Age 40)

Such sacrifices and risk evidence the re-enactors dedication to worshiping national history, building solidarity within the subculture. However, they are also important in helping re-enactors achieve a sense of authentically experiencing the past. This is not only in terms of mimetic understanding of what Civil War soldiers had to endure and the high likelihood of death (cf. Gibson 1994), but in facilitating the required emotional work (Hochschild 1990) to achieve a sense of time travel. In Victor Turner's terms, for re-enactors to attain a sense of living history they must achieve 'flow' (Turner 1982), where the actor gives themselves up to the role, creatively defying the temporal classifications which embed reality. Where this has a trance like quality it is not achieved without environmental influences. As we see in the below quotes the stimulus appropriate conditions, including weather and noise, as well as the self-presentation of other, are particular important in bringing on a heightened sense of living history. 
"Almost impossible to describe without actually being there. When you're looking at a line of men, then all of a sudden there's 3000 rifle muskets all aimed at you. It certainly does get the adrenalin going... That is very close to what it is like" (Confederate, Age 38, Museum Director).

"And sometimes through the smoke and everything and the sound it is almost like being transported back into time... So it is kind of a way of history coming alive to me, that's why I like it." (Union Private, Age 40, Military Soldier)

"Just looking down and seeing the feet and the dust and how your vision is limited if you're in a rear rank or in the middle of a column. All of that and sometimes at night too. The campfires and the way the lighting is really gives you an idea of the way it was." (Union sergeant, Age 46)

However, when this metaphoric time travel is achieved, re-enactors in the interview sample note that it seldom last for any significant period of time. As illustrated in the quotes above, it is something more fleeting. This reflects the contingent qualities and difficulties in producing recreational re-enactments, as discussed in the earlier section of the article. However, this scarcity tends to strengthen the influence of the experience when it is attained and reinforces the desire to engage in the effort required in again achieving it.

\section{Re-enacting and Political Activism}

Unlike other national performances, the significance of re-enacting and the attainment of living history is not in altering the belief system of participants (cf. West 2008b). Unsurprisingly re-enactors already hold a strong commitment to the nation, underpinned by a desire "to revert to the simpler ways of an alleged Golden Age in an earlier lifestyle" (Smith 1986: 175). Where such nostalgia was once widely held, as Hunter $(1991 ; 2006)$ argues, today it is part of a meta-divide and new form of cultural conflict in the United States and the West between those holding two different worldviews, that of orthodoxy and progressivism. The majority of re-enactors subscribe to orthodoxy, ${ }^{9}$ believing in "an external, definable and transcendent authority"(1991:44) that "is predicated upon the achievements and traditions of the past as the foundation and guide to the challenges of the present..." (Hunter 2006:14). Nostalgia from this perspective is not simply backward looking (Eyerman 2004) but seeks from the past "reinvigoration and realization of what are considered to be the very noblest ideals and achievements of civilisation (Hunter 2006: 14). Progressives, by contrast, are "defined by the spirit of the modern age, a spirit of rationalism and subjectivism" and are indifferent to the ideals of patriotism and sceptical towards the relevance of national history (Hunter 1991: 44). As such the interest in the Civil War by re-enactors is inherently political. As indicated in the quotes below, particular orthodox beliefs of most re-enactors include a literal understanding in the significance of God, a strong anti-abortion position, a belief in the inherent differences between men and women, and opposition to a strong welfare state.

“There was a lot more belief in God.... And you don't have all that now. It's a shame that we don't because society is missing the big picture on life" (Confederate, Age 21, Labourer) 
"I think in modern life people have no respect, no responsibilities... I don't believe in abortion. I mean you are killing a baby, you're killing a person..." (Union Captain, Age 40, Motor Mechanic)

"I hope people don't take this wrong but (today) women want to do what men do but back then men did one thing and women did another. That is how I look at it. Women didn't work in the factories, men did. Women stayed at home, sewed, did this did that.." (Confederate Private, Age 21, Factory Worker).

"Back then you worked for it. What you put into it is what you got out of it but in life today you can put your best in (and) you still can't make it. Big brother up there always trying to knock you down" (Confederate, 40 years old, technician)

However, from a performance perspective it is important not to reduce our understanding of re-enactment to the political beliefs of its participants as involvement in symbolic action both plays a significant role in attenuating these and orientating subsequent political action. In Geertz's terms the symbolic frame of performance allows re-enactors to "not only feel but know what we feel and act accordingly."(1973:69).

Civil War re-enactments not only provide an opportunity for like-minded history enthusiasts to gather collectively. Rather the experience of re-enacting itself alters participants, providing them with a belief that they have a newfound insight into how history occurred. Part of being a re-enactor is researching historical sources, focussing on diaries and regimental histories of those directly involved in battles. As such participation in re-enacting does provide participants with certain intellectual knowledge. However, as outlined below, the majority of knowledge claimed is not only of this trivial nature but this combine with and underpins more overtly ideological understandings of the past. Re-enactors are able to do this by having achieved what I term as affective authority, a claim to know the past through experiential and empathetic experience of it (Crang 1996). This is not simply an alternative way of understanding the war that focuses on minutiae and the first person perspective. Rather it involves a rejection of established historical understandings of the past in terms of socio-political shifts and conflicts. Such anti-intellectualness not only promotes a commitment to the culture of re-enacting but is utilised in endeavouring to alter understandings of the war by those outside of it.

If we can get one person to change their attitude or rethink their opinions and give them a new direction we really have done a whole lot" (Union Private, Retired Prison Guard, Age 42)

"The only way the story is really going to be told is by people who really do their research, really learn, live it and show it" (Union Private, Age 55).

This principally occurs through re-enactors engaging in frequent voluntary educational activities with the public. These are undertaken in a variety of seeting, including in local schools where teachers often take up offers by re-enactors to come into the classroom, seeing this as a strategy for enhancing student learning. Re- 
enactors also frequently undertake encampments outside and within museums, with the historical understandings of re-enactors empowered by being associated with a more established remembrance institution. Re-enactors too engage with both young and old spectators at re-enactment, either as the public wander through camps or as part of formally set up educational sites within the re-enactment. So orientated is the culture of re-enacting to the achievement and use of their affective authority that many re-enactors prefer to refer to themselves as history teachers. Re-enacting manuals too stress teaching others about the past from a living history perspective as being core to what re-enacting involves, outlining various techniques including first person accounts where the re-enactor adopts a particular historical identity. Where third person accounts are suggested the emphasis is on "the interpretation of what you feel and think as you play the part" using "period clothing, accoutrements, and artefacts as the tools of interpretation" (Hadden 1996: 11-12).

This teaching though does not simply aim to encourage a greater awareness of the Civil War but is directed at challenging dominant historical accounts which they see as misrepresenting the past. The focus on minutiae and the everyday is connected with a desire to rescue this key historical national moment from intellectual accounts of history which view the past negatively in reference to contemporary rights and equalities.

"What you receive in your history classes is a filtered down version and the politically accepted version of what happened. And you learn through reenacting and research of your units and research of battles and research of people through local records and through personal accounts and diaries that what you learnt in school is not what it was at all. It was very different." (Confederate, Age 38, Museum Director)

"Being a re-enactor makes you understand it more, understand out forefathers more, what they went through. And they had guts, true heart. I mean they suffered and reading books doesn't let you comprehend it until you go actually out and do this. When you start doing it and you get wrapped up into it, you understand! (Union, Age 41, Handicap Instructor)

The attack against progressive historical revisionism, indicated in the above quotes, is focussed on the particular issue of slavery. Most re-enactors, from both Union and Confederate armies, propagate in their educational activities that the Civil War was not fought over the issue of slavery.

"It's a lot of fun going out there and blowing powder and playing war but the main part of it is teaching the public exactly what went on because a lot of them think it was fought over slavery which it wasn't. It was fought over state's rights" (Confederate, 40 years old, technician)

"I guess you almost become more of a crusader for the truth. Because you are learning you want to go out and say hey everybody it wasn't just fought to free the slaves, it was so much more than that the way it started out." (Age 50, Union Captain) 
The Civil War and slavery has been a continual site of cultural politics and a central trauma narrative around which Afro-Americans have become culturally accepted as full United States citizens (Eyerman 2002). As Barry Schwartz notes, a key aspect of this has been the historical linking of Abraham Lincoln and the Emancipation Proclamation (Schwartz 1997) to modern civil rights beliefs about racial equality. To challenge the contemporary tie between slavery and the Civil War is not necessarily historically inaccurate but it does seek to untangle the cultural basis around which the majority of black community in the United States have been able to legitimately identify themselves as being both American and of African heritage. Political orthodoxy rejects such cultural hybridity, arguing for a more rigid form of equality in terms of national assimilation. However, this is not a typical modernist insistence on national boundaries (Bauman 2000), for as we have seen the experience of living history that unpins it involves a "fuzzy" creative mind and the cognitive collapsing of modern classifications (Zerubavel 1991). As such I argue that rather than the power of re-enacting only reflecting some larger socio-structure it is performative and involves the attainment and utility of an affective authority. Where prior to being re-enactors these actors may have expressed similar opinions about history, it is their experience and status of being re-enactors that provides the access to engage in educational activities with the public.

The focus of this paper has been on the experience of re-enacting and its motivating effects and as such has not examined in any detail the actual influence of the educational activities that re-enactors undertake. However, in identifying the prominence of living history in popular culture I have alluded to the increasing significance of affective forms of understandings the past. Where Hunter $(1991 ; 2006)$ has been utilized in categorizing the worldview of re-enactors as orthodox, I do not similarly suggest that there is an polarization of political viewpoints into two equally sized camps. Rather, as attitudinal survey research has documented, orthodoxy continues to be a minority position (DiMaggio et al. 1996). From this perspective, however, Civil War re-enacting can be thought of as one of a number of ways that orthodox groups in the United States have in recent decades become politically mobilized to attain an unprecedented influence within the public sphere. Where it was argued that living history provided an important paradigm of knowledge for this political activity by Civil War re-enactors, such logics should be thought of as being open to a number of political positions. While the majority of re-enactors, through challenging the tie between the issue of slavery and the war, advance a conservative racial agenda, within re-enacting this is also subject to a counter-performance by the twenty African-American orientated Civil War re-enacting units in the United States (Fields-White 2011). Encouraged by the popular Hollywood film Glory (1989) that depicted the all-black 54th Massachusetts Voluntary Infantry, many of these reenactors were part of the President Barack Obama's inauguration parade. The logics of living history have also been used to address the issue of gender. This is particularly evident in the much publicised sex discrimination suit by Lauren Cook Burgess who was banned from undertaking Civil War battle re-enactments on the basis of gender. Cook subsequent won the case by highlighting that women through cross dressing did fight as front line soldiers during the war (Young 1999:288).

\section{Conclusion}


In applying the performance perspective to Civil War re-enacting the paper demonstrated its utility for nationalism scholars in accounting for the new stylized ways that various groups are engaging with national history. This goes beyond accounts of the enduring influence of the nation within everyday and mundane representations. In the terms of cultural sociology the study highlighted how the nation can be conceived as a cultural symbol while simultaneously accounting for social conflict and political action in concrete ways. Where a cultural sociological conception of performance has been previously applied to various kinds of national engagement, I have argued that these studies have dialectically conceived of performance in terms of their production and reception by audiences. Where this facilitated performance being applied to macro issue of meaning-making, accounting for the role of symbolic power in directing social conflict and social change, it tended to neglect the political significance being actively involved in national performances. Drawing on Geertz $(1973,1983)$ the study highlighted how re-enactors engaged with the past in ways that produced distinctive moods and provided affective experiences. While the experience of re-enacting was highly variable, reflecting the dynamics and practicality of performance, all re-enactors interviewed noted that they had at various times achieved their aim of losing historical consciousness, believing that they have attained an authentic insights into what it was like, if only fleetingly, to be engaged in the Civil War. The influence of this experience though was not only to bonds participants into this subculture, but significantly in providing an affective authority that facilitated subsequent political advocacy. This principally occurred through voluntary educational activities in which re-enactors took aim at established historical narratives and those who uphold them, in particular the belief that the Civil War was fought over the issue of slavery. While this is significant for the appreciation of ethnicity within the United States, drawing on Hunter $(1991,2006)$ it was argued that the issue of slavery was but one aspect of a larger 'culture war' in between orthodox and progressive groups. This finding challenges postmodern social theory that has generally assumed that leisure orientated engagement with the past represents a weakened and depoliticised engagement with it. Where the performance analysis of Civil War re-enacting highlighted its fragmented and carnivalesque qualities, it demonstrated that these can result in an even more heighted emotional engagement with the past and achieving a sense of having authentically come to know what it was like to fight in the Civil War.

\section{References}

Agnew, V. (2007) “History's Affect Turn: Historical Reenactment and its Work in the Present” Rethinking History 11(3): 299-312.

Alexander, J.C. (2003) The Meanings of Social Life Oxford: Oxford University Press.

Alexander, J.C. (2004a) "From the Depths of Despair: Performance and CounterPerformance on September 11th" Sociological Theory 22(1): 88-105.

Alexander, J.C. (2004b) "Cultural Pragmatics: Social Performance between Ritual and Strategy" Sociological Theory 22(4): 527-573.

Alexander, J.C. (2011) Performative Revolution in Egypt London: Bloomsbury. 
Alexander, J, and Smith, P. (2010) "The Strong Program: Origins, Achievements and Prospects" in J. Hall (ed) Handbook of Cultural Sociology London: Routledge.

Alfred, R. (1996) "Catharsis, Revision and Re-enactment: Negotiating the Meaning of the American Civil War" Journal of American Culture 19(4): 1-13.

Anderson, B. (1983) Imagined Communities: Reflections on the Origins and Spread of Nationalism London: Verso.

Anderson, J. (1982) "Living History: Simulating Everyday Life in Living Museums" American Quarterly 34: 290-306.

Anderson, J. (1985) The Living History Sourcebook Nashville: American Association for State and Local History.

Bakhtin, M (1984) Rabelais and his World Bloomington: Indiana University Press.

Baudrillard, J. (1983) Simulations. New York: Semiotext(e).

Bauman, Z. (2000) Modernity and the Holocaust Ithaca, N.Y.: Cornell University Press.

Berezin, M. (1997) Making the Fascist Self: The Political Culture of Inter-war Italy Ithaca: Cornell University Press.

Billig, M. (1995) Banal Nationalism London: Sage.

Bodnar, J. (1992) Remaking America: Public Memory, Commemoration, and Patriotism in the Twentieth Century. Princeton: Princeton University Press.

Brubaker, R. and Feischmidt, M. (2002) "1848 in 1998: The Politics of Commemoration in Hungary, Romania and Slovakia" Comparative Studies in Society and History 44: 700-744.

Butler, J. (1999) Gender Trouble: Feminism and the Subversion of Identity. New York: Routledge.

Calhoun, C. (2003) "'Belonging' in the Cosmopolitan Imaginary" Ethnicities Vol 3(4): 531-568.

Conway, B. (2007) "Moving through Time and Space: Performing Bodies in Derry, Northern Ireland" Journal of Historical Sociology 20(2): 103-125.

Crang, M. (1996) "Magic Kingdom or a Quixotic Quest for Authenticity?" Annals of Tourism Research 23(2): 415-431.

Denzin, N. (2003) Performance Ethnography: Critical Pedagogy and the Politics of Culture London: Sage. 
DiMaggio, P., Evans, J. and Bryson, B. (1996) "Have Americans' Social Attitudes Become More Polarized?" American Journal of Sociology 102(3):690-755.

During, S. (2007) "Mimic Toil: Eighteenth-Century Preconditions for Modern Historical Reenactment" Rethinking History 11(3): 313-333.

Durkheim, E. (1995)[1912] The Elementary Forms of Religious Life New York: Free Press.

Edensor, T. (2001) "Performing Tourism, Staging Tourism: (Re)producing Tourist Space and Practice" Tourist Studies 1(1): 59-81.

Eyerman, R. (2002) Cultural Trauma: Slavery and the Formation of African American Identity Cambridge: Cambridge University Press.

Farmer, J.O. (2005) "Playing Rebels: Reenactment as Nostalgia and Defense of the Confederacy in the Battle of Aiken" Southern Cultures 11 (1): 46-73.

Fields-White, M. (2011) "Black Civil War Re-enactors Reclaim History" The Root Posted: May 5, 2011 at 12:46 AM: Last accessed January 19, 2012:

http://www.theroot.com/views/black-civil-war-re-enactors?page $=0,2$

Foucault, M. (1977) Discipline and Punish London: Penguin.

Fox, J. and Idriss-Miller, C. (2008) “Everyday Nationhood” Ethnicities 8(4): 536-563.

Geertz, C. (1972) "Deep Play: Notes on the Balinese Cockfight" Daedalus 101(1): 137.

Geertz, C. (1973) Interpretation of Cultures New York: Basic Books.

Geertz, C. (1983) Local Knowledge. New York: Basic Books.

Gibson, J.W. (1994) Warrior Dreams: Paramilitary Culture in Post-Vietnam America New York: Hill and Wang.

Goffman, E. (1974) The Presentation of Self in Everyday Life London: Penguin.

Hadden, R.L. (1996) Reliving the Civil War: A Reenactor's Handbook Mechanicsburg, PA: Stackpole Books.

Halbwachs, M. (1950) The Collective Memory New York: Harper \& Row.

Hall, D. (1994) "Civil War Reenactors and the Postmodern Sense of History", Journal of American Culture 17(3):7-10.

Hochschild, A.R. (1990) "Ideology and Emotion Management" In T.D. Kemper (ed) Research Agendas in the Sociology of Emotions Albany: State University of New York Press: 117-142. 
Horwitz, T. (1998) Confederates in the Attic: Dispatches from the Unfinished Civil War New York: Pantheon Books.

Hunter, J.D. (1991) Culture Wars. New York: Basic Books.

Hunter, J.D. (2006) 'The Enduring Culture War', pp. 10-40 in J.D. Hunter and A. Wolfe (eds) Is There a Culture War? Washington, DC: Brookings Institution Press.

Jacobs, R. (2000) Race, Media and the Crisis of Civil Society. Cambridge: Cambridge University Press.

Kaufman, W. (2006) The Civil War in American Culture Edinburgh: Edinburgh University Press.

King, A. (forthcoming) The Combat Soldier: Infantry Tactics, Cohesion and Professionalism Oxford: Oxford University Press.

Mast, J. (2006) "The Cultural Pragmatics of Event-ness: The Clinton/Lewinsky Affair" in Alexander, J.C., Giesen, B. and Mast, J.L. (eds) Social Performance: Symbolic Action, Cultural Pragmatics and Ritual Cambridge: Cambridge University Press: 115-145.

Melucci, A. (1996) The Playing Self: Person and Meaning in the Planetary Society New York: Cambridge University Press.

Radtchenko, D. (2006) "Simulating the Past: Reenactment and the Quest for Truth in Russia” Rethinking History 10(1): 127-148.

Schecher, R. (1977) Ritual, Play, and Social Drama. New York: Seabury Press.

Schwartz, B. (1997) "Collective Memory and History: How Abraham Lincoln Became a Symbol of Racial Equality” The Sociological Quarterly 38(3): 469-496.

Schwartz, B. (1996) "Memory as a Cultural System: Abraham Lincoln in World War II" American Sociological Review 61(5): 908-927.

Shils, E. (1995) "Nation, Nationality, Nationalism and Civil Society" Nations and Nationalism 1(1)93-118.

Smith, A.D. (1986) The Ethnic Origins of Nationalism Oxford: Blackwell.

Smith, A.D. (1995) Nations and Nationalism in a Global Era Cambridge: Polity Press.

Spillman, L. (1997) Nation and Commemoration: Creating National Identities in the United States and Australia Cambridge: Cambridge University Press.

Stanton, C. (1999) "Values and Perceptions: The Battle over Battles" in Reenactors in the Parks http://www.nps.gov/revwar/reenactors/section2.pdf 
Strauss, M.D. (2003) "Identity Construction Among Confederate Civil War Reenactors: A Study of Dress, Stage Props, and Discourse" Clothing and Textiles Research Journal 21(4): 149-161.

Sturken, M. (2007) Tourists of History: Memory, Kitsch, and Consumerism from Oklahoma City to Ground Zero Durham, N.C.: Duke University Press.

Taylor, D. (2003) The Archive and the Repertoire: Performing Cultural Memory in the Americas Durham, N.C.: Duke University Press.

Thompson, J. (2004) Inside the World of $20^{\text {th }}$-Century War Reenactors Washington DC: Smithsonian Books.

Turner, V. (1969) The Ritual Process Chicago: Aldine.

Turner, V. (1974) Drama, Fields and Metaphors: Symbolic Action in Human Society Ithaca: Cornell University Press.

Turner, V. (1982) From Ritual to Theatre: The Human Seriousness of Play. Baltimore, MD: PAJ Press.

West, B. (2008a) "Collective Memory and Crisis: The 2002 Bali Bombing, National heroic Archetypes and the Counter Narrative of Cosmopolitan Nationalism" Journal of Sociology 44(4): 337-353.

West, B. (2008b) "Enchanting Pasts: The Role of International Civil Religious Pilgrimage in Reimagining National Collective Memory" Sociological Theory 26(3): 258-270.

Winter, J. (1995) Sites of Memory, Sites of Mourning: The Great War in European Cultural History. Cambridge: Cambridge University Press.

Young, E. (1999) Disarming the nation Chicago: University of Chicago Press.

Zerubavel, E. (1991) The Fine Line New York: Free Press.

\footnotetext{
${ }^{1}$ This research was facilitated by visiting scholarships in the sociology departments at Gettysburg College and the University of Georgia.

${ }^{2}$ Where Alexander does note that not all performances require an audience (2004b: 531), the power such rites and what they tell us about performance is not considered.

${ }^{3}$ It is thought that the number actively involved in Civil War re-enacting has recently declined, most likely as a consequence of the economic downturn which make involvement difficult in this relatively expense hobby. The least expensive form of re-enactment is of infantrymen in which essential equipment is considered a musket, bayonet and scabbard, coat, trousers, shirt, belt and buckle, boots, canteen, haversack, cap box, cartridge box, sling, slouch hat or kepi and brass insignia (Hadden 1996:40). Current estimates to purchase these goods is over USD $\$ 1000$.

${ }^{4}$. While this is most evident in hardnosed postmodern theory, social theory has generally assumed that leisure orientated engagement with the past represents a weakened and depoliticised engagement with it. This is evident in Weberian orientated scholarship where aesthetic forms of national remembrance
} 
are seen as signifying a desacralisation of history and routinisation of historical charisma (e.g. Brubaker and Feischmidt 2002).

${ }^{6}$ The embodied engagement with the past that re-enacting provides differs from established modern forms of national remembrance. Anderson (1983), for example, proposes that the tomb of the unknown soldier is emblematic of national commemoration, arguing that the ambiguity surrounding the identity of whom lies within facilitates an inclusive imagining of oneself as part of the nation and a deference to the state in giving meaning to the past (Anderson 1983:9). Such symbolism is consistent with Durkheim's ([1912] 1995) understanding of the sacred as something beyond comprehension and not to be touched. So strong is the awe inspired by the sacred that Durkheim argued that it has "a certain horror" and that the reverence that it invokes is not unlike "the fear inspired by malignant powers" ([1912]1995:412-414). In re-enactment, however, participants do not distant themselves from the sacred but directly engage and attempt to metaphorically become part of it. In this sense re-enactment has similarities with pilgrimages, a ritual Victor Turner (1974) has argued involves a direct touching of the sacred and as such has tended to be inveterately popularist and anarchical, having throughout history being associated with popular nationalism, peasant revolt, and millenarianism.

7 This cultural divide is illustrated in a NPS study into their relationship with re-enactors with many personnel being troubled by both the desire of reenactors to recreate combat and the impossibility to do so accurately, with battle re-enacting providing spectators with a stimulating but eventually sanitised portrayal of the destructive horror of war (Stanton 1999:23).

${ }^{8}$ There are American Civil War re-enacting regiments located in Australia, Canada, Germany, Italy and the United Kingdom. 